\title{
Investigating the Source of Motivation for Online Learning
}

Mazlan Che Soh, Fadilah Puteh, Mohammad Bastyian Mahmud, Memiyanty Abdul Rahim, Agie Nugroho Soegiono, Noor Hanim Rahmat

To Link this Article: http://dx.doi.org/10.6007/IJARBSS/v12-i1/11411

DOI:10.6007/IJARBSS/v12-i1/11411

Received: 05 November 2021, Revised: 08 December 2021, Accepted: 24 December 2021

Published Online: 13 January 2022

In-Text Citation: (Che Soh et al., 2022)

To Cite this Article: Che Soh, M., Puteh, F., Mahmud, M. B., Abdul Rahim, M., Soegiono, A.G., \& Rahmat, N.M. (2022). Investigating the Source of Motivation for Online Learning. International Journal of Academic Research in Business and Social Sciences, 12(1), 2189-2208.

\section{Copyright: (c) 2022 The Author(s)}

Published by Human Resource Management Academic Research Society (www.hrmars.com)

This article is published under the Creative Commons Attribution (CC BY 4.0) license. Anyone may reproduce, distribute, translate and create derivative works of this article (for both commercial and non0-commercial purposes), subject to full attribution to the original publication and authors. The full terms of this license may be seen at: http://creativecommons.org/licences/by/4.0/legalcode

Vol. 12, No. 1, 2022, Pg. 2189- 2208

Full Terms \& Conditions of access and use can be found at http://hrmars.com/index.php/pages/detail/publication-ethics 


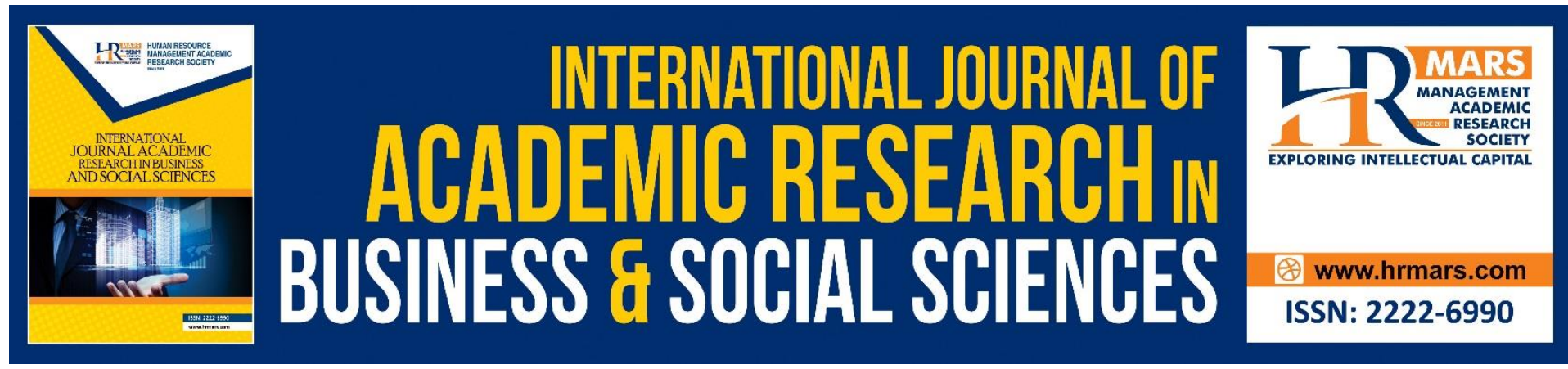

\title{
Investigating the Source of Motivation for Online Learning
}

\author{
Mazlan Che Soh ${ }^{1}$, Fadilah Puteh², Mohammad Bastyian \\ Mahmud $^{3}$, Memiyanty Abdul Rahim ${ }^{4}$, Agie Nugroho Soegiono ${ }^{5}$, \\ Noor Hanim Rahmat ${ }^{6}$ \\ ${ }^{1,2,3,4}$ Faculty of Administrative Science \& Policy Studies, Universiti Teknologi MARA, ${ }^{5}$ Fakultas \\ Ilmu Sosial dan IImu Politik, Universitas Airlangga, ${ }^{6}$ Akademi Pengajian Bahasa, Universiti \\ Teknologi MARA Cawangan Johor, Campus Pasir Gudang
}

\begin{abstract}
Motivation in learning is somehow very important in most subjects that involve a high degree of interaction. These are relevant to subjects such as Social Marketing that rely on group projects and involvement between learners and people, especially in communicating their messages on campaigns on social issues. Compared to the scenario before the pandemic which the learning process was conducted through a formal one-to-one classroom, however, the pandemic has given both teachers and students teaching/learning to accept online learning as the new norm. Though this new environment somehow affects their motivation to learn. Understanding the both contexts of teachers and learners is crucial in making sure they are able to play their different roles to make the lessons successful and meaningful. This quantitative study is done to investigate how is learner's motivation online learning presence is influenced by learners' motives to study a Social Marketing subject. 89 respondents were purposely chosen from learners who took the course. The survey used has 24 items using 5 Likert scales. Findings revealed that the most satisfying thing among students in this program is trying to understand the content of the courses. Learners aim to get a good grade in the classes and that is among the most satisfying things for them. Expectancy components revealed students' perception of self-efficacy in which they believe they will receive excellent results and the belief they had control beliefs for learning. As for affective components, the study revealed that students feel their heart beating fast when they take an exam.
\end{abstract}

Keywords: Social Marketing, Motivation, Expectancy, Affective, Value

\section{Introduction}

Background of Study

Motivation has different meaning to different people and it also reliant on the context or setting as well. A general meaning of motivation is defined as the reason that moves us to do anything (Filgona et al., 2020; Nurul Astuty, 2019); a psychological construct (Filgona et al., 2020; Motevalli et al., 2020); an act, understand, believe, or causes that drives a person to do and know something or satisfy their needs (Filgona et al., 2020; Dyah \& Rochmawati, 2019; Motevalli et al., 2020). 
In the context of learning, it is imperative to define what learning motivation is. Astuty (2019) echoes learning motivation as a boost factor for a student to engage in learning activities with the aim to achieve something beneficial from the learning process. While Dyah \& Rochmawati (2019); Motevalli et al (2020) argue that it is a combination of both extrinsic and intrinsic features that motivate students to engage and show best interest in the whole learning process. Motevalli et al (2020) also concur that in learning, besides behavior, motivation is identified as one of the key elements that drive students to reap knowledge and acquire new things.

As such, motivation can bring different meanings and context to a different people. It is a situation or condition that stimulus or drives men to do something that they desire to achieve or accomplish. How do we know that a student is motivated? We can know this when students start giving full attention in the class, actively participate in the classroom discussion, they come early to class, they submit their tasks on time and many more signals that one can know whether the students are motivated.

A large body of literatures discusses on assorted motivational issues among students in the classroom setting. Rufii \& Dyah Rochmawati (2019) highlighted several issues amongst others limited student engagement, lack of alternative support, and lack of feedback in learning and growth. Meanwhile, Leal-soto et al (2018) contends that work engagement of the teachers coupled with teaching practices with motivational effects correlates significantly with students learning oriented classroom motivation. This implies that lacking these elements led to motivational issues among students in the class. Interestingly, a study by Rana et al. (2019) discover that stress among students is also one of the underlying issues regarding students' motivation in the class.

\section{Thus, This Study Intends to}

- Gauge on source of factors that do influence and motivates students in learning

- To discover the actual source of motivations that make students engage in the learning process.

\section{Statement of Problem}

Researchers and educators have long been interested in motivating learners as it is associated with success and desired outcomes. Motivation provides students with a purpose and direction to follow. For this reason, it has a great significance in learning. However, in the case of insufficient motivation, some problems begin to appear. Educators need to identify the causes of lack of motivation and know how to deal with students who lack motivation (Daggol, 2013). When students have low self-confidence and low self-esteem, anxiety and inhibitions, their motivation level is destroyed. Highly motivated students were found to outperform those with less motivation when they are learning (Vibulphol, 2016). Without motivation, students may not start learning at all, and those who have started learning may not be able to continue their learning if they have difficulties in the process. According to Elena (2021), stated that the educators around the world have seen a significant drop in student motivation, interest, and participation after the launch of online courses in Spring 2020. One of the study conducted by Meeter and Bele (2020) with a sample of 15,125 students from a large Dutch research university - confirmed teachers' assumptions and found that students rated online education as less satisfactory than campus education, 
and their own motivation rated as having declined. Esra and Sevilen (2021) found that participants' extrinsic and intrinsic motivation was lower in online education than in face-toface education and researchers argued that the lack of interaction with peers and teachers is why students are less motivated in online courses. Students reported higher motivation levels due to satisfactory teacher feedback and adequate communication with teachers which in line with Ushida's (2005) study that teachers play an important role in creating a classroom culture that eventually affects students' motivation.

Hence, this study is done to explore the influence of motivation on learners. Specifically, this study is done to answer the following questions

RQ 1-How do value components influence learners' motivation?

RQ2-How do the expectancy components influence learners'

motivation?

RQ3-How do the affective components influence learners'

motivation?

\section{Literature Review}

Demotivation for Learning

Dörnyei \& Ushioda (2013) defined demotivation as a drop or decrease in level of motivation. Demotivation does not result from a regular loss of interest across a period of time, internal trigger or distractions of a more attractive choice. External locus is where the demotivation starts a demotivating trigger, before it develops an internalized process, and motivation should occur before there can be a subsequent decrease. Absence of any motivation is the state of amotivation, marked by passivity. Vallerand and Ratelle (2002) stated that amotivated people feel a lack of control or competence over their external environment. They feel helpless due to the lack of contingency between their behaviours and outcomes. People with no motivation will go through their task with no real intention to do what they are doing until they quit the activity (Ryan and Deci, 2002, p. 17). Gorham \& Christophel (1992) compiled reasons of what learners perceived as their demotivation in university classrooms in a diversity of academic subjects. After they compared the learner attributions of demotivation and motivation, it showed that the absence of demotivators in the classroom such as boring subject, dissatisfaction with grading and unenthusiastic teaching had a more positive influence on motivation than the presence of motivators such as passionate and exciting teacher. It can be concluded that the motivators such as teacher could encourage learner motivation purely by avoiding demotivation. Falout, Elwood, \& Hood (2009) carried out study that find out the relationship between student motivation and demographic variable such as age, gender and proficiency level.

\section{Motivation for Learning}

It is crucial to motivate students to learn because better academic results can be achieved if the student had substantial motivation to succeed compared to those who has not (Juhana, 2012). Based on the self-determination theory by Deci \& Ryan (1985), motivation can be categorized into two types: intrinsic motivation which is an internal force that makes something naturally entertaining and enjoyable to do, and extrinsic motivation which refers to behaving for a desired outcome. 
From another perspective, Vroom and Deci (1970) found that there are several factors influenced the motivation in doing something. As mentioned in figure 1, Vroom \& Deci (1970), in their expectancy theory states that motivation is an outcome of how much an individual wants a reward (Valence), the assessment that the likelihood that the effort will lead to expected performance (Expectancy) and the belief that the performance will lead to reward (Instrumentality). With regards to social marketing course, in which involves with a combination of group projects that comply students with the capabilities in interpersonal and communication skills, the learners' motivation is the drive that pushes them to put effort (Expectancy). In the learning of subject with the skills of communication and interpersonal skills in which they need to interacts with all level of people in society (Social Marketing), learners began with their expectation (Expectancy) of what they will get (Instrumentality) after they have completed learning (Rewards).

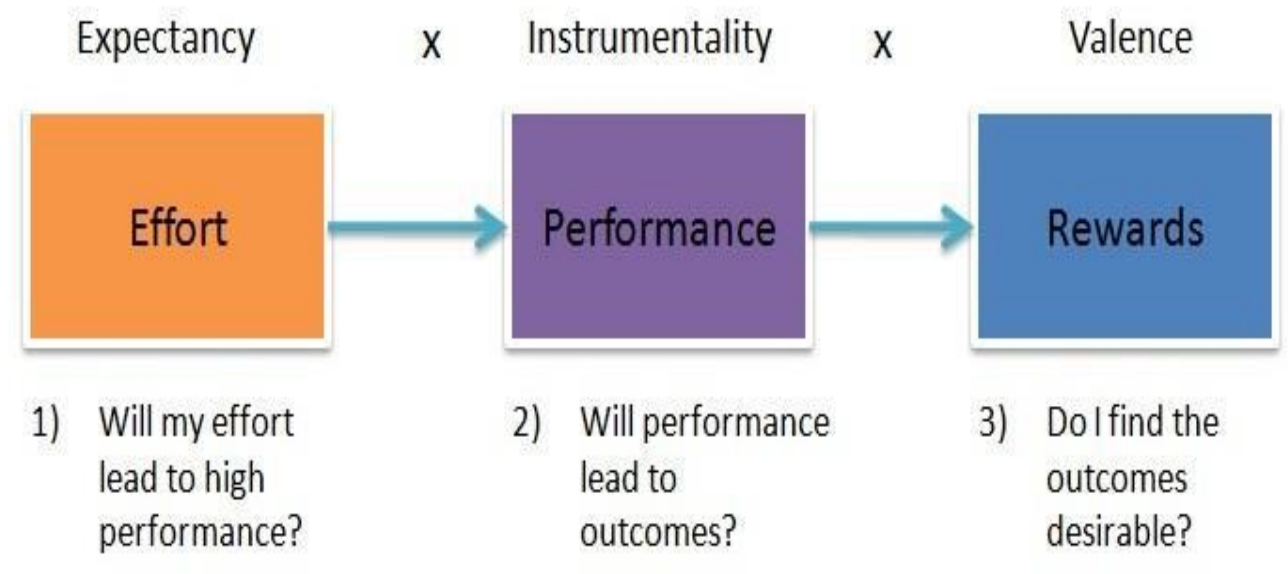

Figure 1: VIE Theory (Vroom \& Deci, 1970)

Palmer (2007) revealed that among the indicators anyone is motivate to learning among others are they pay attention, they begin working on tasks immediately, they ask questions and volunteer answers, and they appear to be happy and eager.

In her research on motivating factors for students with low emotional intelligence to participate in speaking activities, Mendez Lopez and Batista Tun (2017) found that there is difference between male and female. As for male participants, Mendez found that goal oriented performance, neutral corrective feedback and supportive classroom community there are among the motivating factors. Otherwise, for the female participants, the study found that interacting with native speakers and supportive classroom community are among other factors which influence their motivation to learn.

\section{Past Studies}

This section deliberates on the factors that demotivate learners or students to learn. Several past studies were reviewed to identify what causes them to loss their interest in learning. A study by Williams \& Williams (2011); Rufii \& Dyah Rochmawati (2019) concur that there are five key ingredients for improving student motivation namely (1) student; (2) teacher; (3) content; (4) methods/process; and (5) environment. Any dissatisfaction to the key ingredients resulting in demotivation to the students to engage in learning. A study by Rana et al (2019) argue that all these five key ingredients could be the source of stressors which led the students to feel demotivated in learning. 
A study by Tapia et al (2020) to figure out the causes, effects, and implications regarding differences in classroom motivational climate revealed an interesting finding. Using teacher's motivational quality (TMQ) and Classroom Motivational Climate (CMC) items, the sample of the study involved both students and teachers in the classroom context. Data obtained was analyzed using SEM. It was found that TMQ has indirect effect on differences between classrooms in CMC as well as students' attribution of perceived improvement in motivational variables to teachers. They further argue that teachers' characteristics differ in their contribution to both TMQ and CMC. This study implies that students motivational in class is closely related and influenced by the role of teachers' knowledge, goals, and expectancies to their students. If their teacher shows some interest in them, have positive motivational knowledge, have clear goals towards their students will determine how their students perform in class.

Another study by Ashinida Aladdin (2013) on factors that demotivates learners to learn was carried out to identify factors that demotivates non-Muslim Malaysian learners to learn Arabic. Using open ended questionnaire and semi-structured interviews to 207 students, findings of this study revealed nine (9) demotivating factors namely (1) Arabic subject-related factors, (2) Teacher-related course, (3) class related factors, (4) negativeattitudes towards foreign language, (5) course materials and learning contents, (6) the compulsory nature of Arabic study, (7) time constraints, (8) lack of opportunities to communicate in Arabic, and (9) lack of ability. Findings of this study suggest that there are number of reasons that demotivate learners to learn, and this psychological feeling combined with lack of motivational desire led the situation from bad to worse if not handled wisely.

In another study also looked at factors that demotivates students to learn. A mixed methods research by D'Orazzi (2020) was done to investigate universities students' demotivation in learning second languages in Australian universities. Employing both survey and interviews approaches, encompasses of 8 Australian universities students who took French, German, Italian and Spanish languages in these universities. This study found three (3) main factors derived from survey namely (1) socio-cultural environment at the macro level, (2) learning environment at the meso level, and (3) psychology of the language learners at the micro level. These 3 level model are further divided into several sub-components derived from interview findings. The findings of the study imply that the factors and the sub-components of the factors are varies depending on the context and the learners background.

It is also noted that findings of the above studies suggest that factors that demotivate learners to learn can be classified further under five key ingredients as pointed by (Williams \& Williams, 2011; Rufii \& Rochmawati, 2019)

\section{Past Studies on what motivates Learners}

Filgona, Sakiyo, Gwanyand and Okoronka (2020) indicates motivation as a process that begins with physiological deficiency or need that enacts a conduct which is focused at a goal or incentives. This is the reason why motivation is alluding to as "the reasons underlying behaviour". Learners dole out different implications and mentalities to scholastic exercisesindividual implications and perspectives that stimulate and direct their energies in various ways. These related stimulating and coordinating impacts are alluded to as inspiration or in some cases inspired them to learn. They indicated that an educator or teacher whose shows 
positive attitude and enthusiasm for learning in a particular educational programs or specific curricula subject will foster positive affect and enthusiasm for the learners to learn and accomplishment in the subject.

The study by Esra and Sevilen (2021) was done to investigate the impact of online education on learner's motivation using a semi-structured interview and creative writing assignments to understand their perceptions on motivation in the virtual classrooms. There were 18 students involved from a non-profit private university. They were given the topic of advantages and disadvantages of online education. They conducted a thematic analysis from an inductive perspective were the data have been transcribed and coded as below diagram.
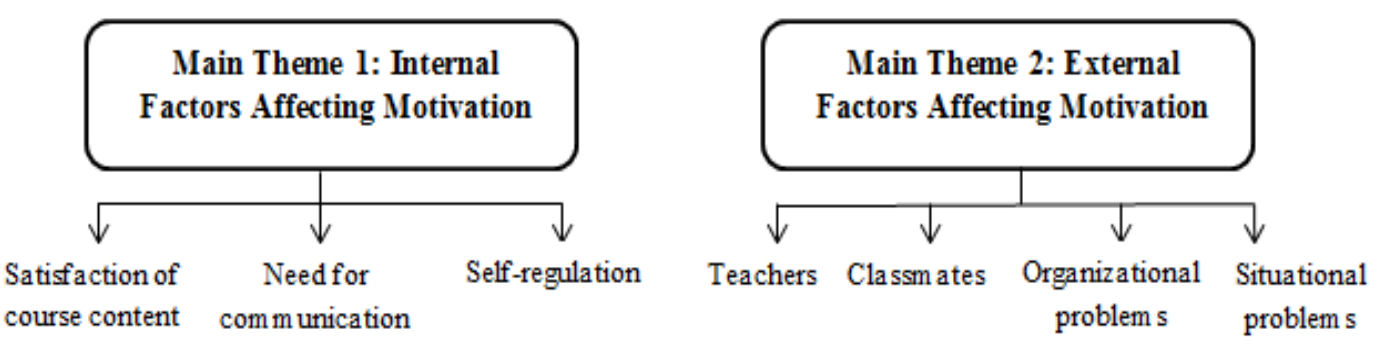

Figure 2: Learners' View on Online Instruction (source: Esra \& Seyilen, 2021)

The findings (figure 2) demonstrated that learners' view of online instruction most of the part were negative because lack of interaction between the teachers, classmates and teachers' feedback. Learners reported higher motivation levels as a result of satisfying teacher feedback and sufficient communication with teachers (Esra and Sevilen, 2021). Detailed feedback was found to be a motivation booster that made the learners to be more satisfied. They also reported that higher levels of engagement in the activities, classes and tasks were relevant and meaningful to the learners. The enjoyment in the course content and self-discipline were contributed to increased students' motivation.

Another study also looked at teacher's feedback. The study by Elena (2019) was done (figure 3 ) to investigate the levels of students' motivation during distance learning using a simple questionnaire via Google Forms which involved 68 high school students from Year 2 and Year 3. Even though the learning activities were engaging, assigning homework and timely feedback could build their motivation, the students figured out that learning online were to be inadequate as shown below. 


\section{What could increase your motivation during these classeses?}

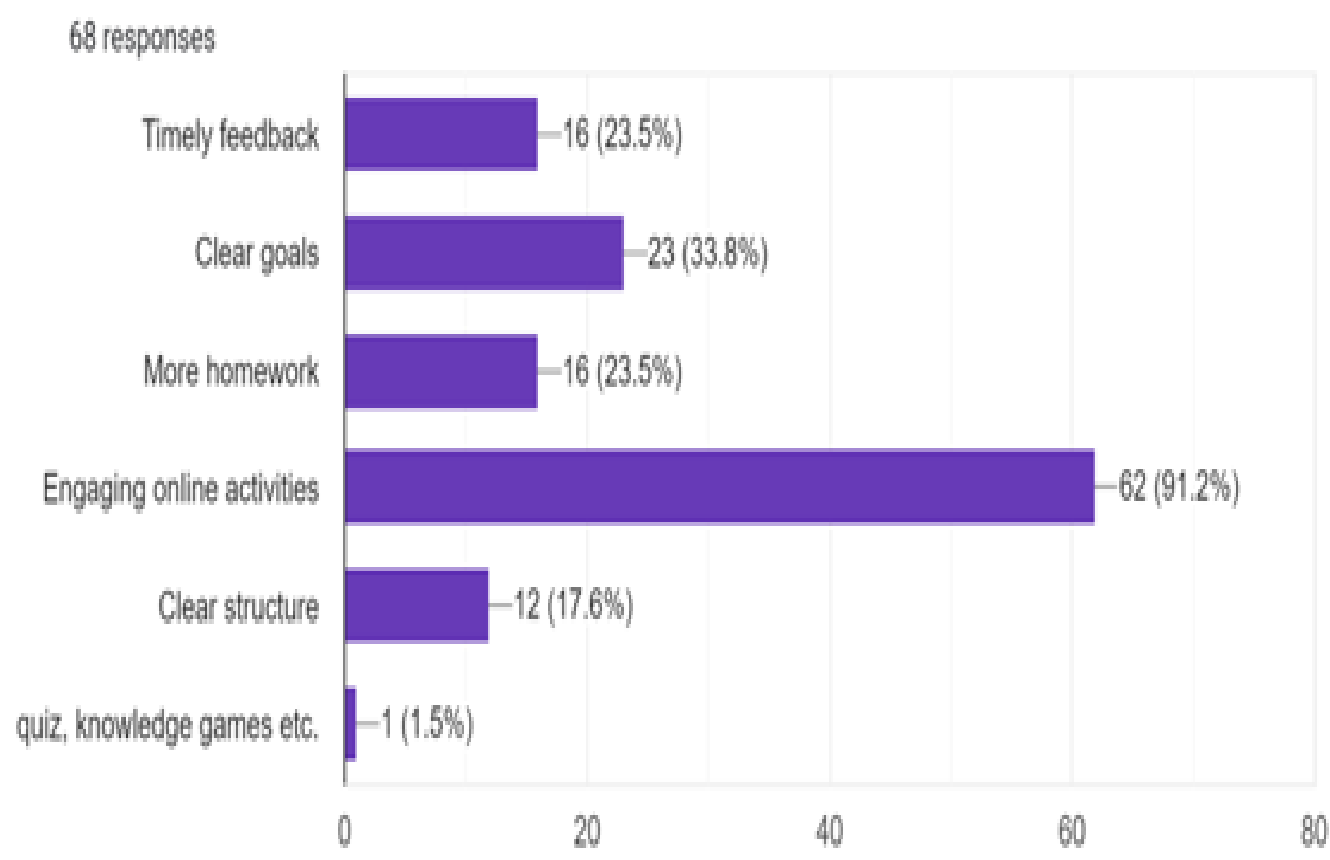

Figure 3: Level of Students' Motivation during distance Learning (Source: Elena, 2019)

\section{Conceptual Framework}

In learning, learners' confidence comes from being comfortable with the knowledge that they received. According to Rahmat, Sukimin, Mok, Anuar and Mohandas (2021), this confidence gives them a sense of satisfaction to the learners. In addition to that, learners need a sense of knowing what they are doing to be motivated to sustain the learning. This study is rooted from the attribution theory by Weiner (1974) and motivation factors by Pintrich, \& De Groot (1990). According to Weiner (1974), learners perceive their learning from three angles; (a) locus, (b) stability, and (c) controllability. Figuratively speaking, locus is the source of success or failure. It can be internal or external. Next, stability is achieved when learners can feel relative permanence of the quality. Controllability is the extent to which the individual can influence the learning. Hence, this study (Figure 4) embedded Pintrich \& De Groot's (1990) motivation factors onto Weiner's (1974) attribution factors to explain learners' motivation. Locus depends on value components. Learners stability depends on affective components and controllability depends on expectancy components.

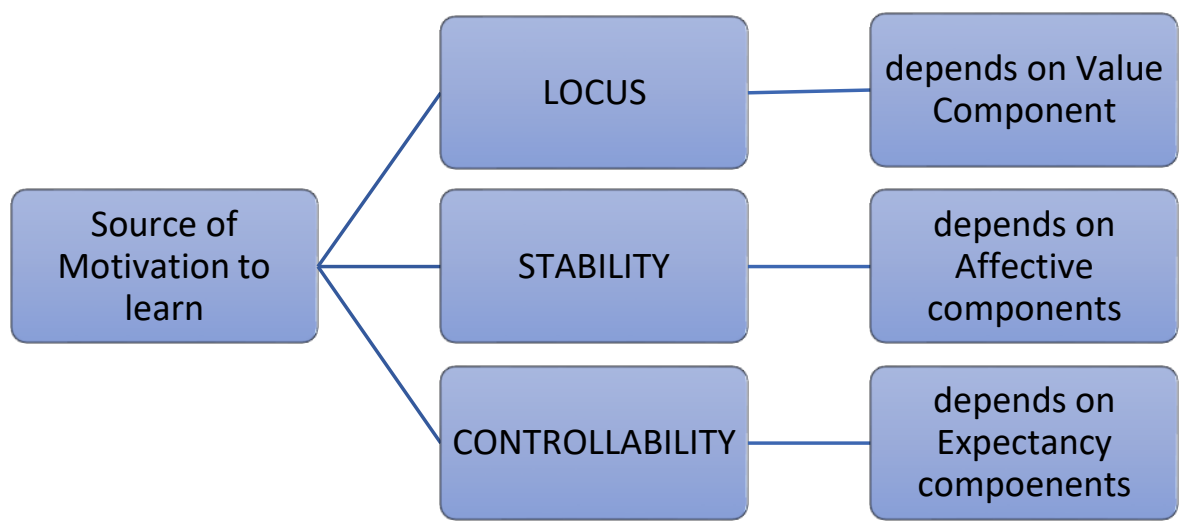

Figure 4- Conceptual Framework of the Study-Source of Motivation to learn 


\section{Methodology}

This study used a quantitative research technique. A total of 89 participants will participated and selected through convenient sampling. The participants will complete the questionnaire through face to face/ online platform and their participation is voluntary. A brief explanation of the purpose of research will be done by the researcher before the questionnaire distribution. The researcher also will ensure the participant to know that their responses would be kept confidential since they don't need to write their names. The respondent's native language (Malay) will be added along with English language to give the respondent the choices to read the questionnaire in their preferable language.

The Data of the study will be collected from questionnaire, which consists of demographic profile and motivational scale. The motivational scale (refer to table 1)is divided into three section which are section A: Value component, section B: Expectancy component and section C: Affective component and each of the section has their own variables. For value component, the variables are intrinsic goal orientation, extrinsic goal orientation and task value beliefs. Other than that, the variables for expectancy component are students' perception of self-efficacy and control beliefs for learning. Other than that, the demographic profile is only divided by two section which are gender and age.

Table 1- Distribution of Items MOTIVATIONAL SCALE (24 items)

\begin{tabular}{|l|l|l|l|l|l|}
\hline SECT & CONSTRUCT & & VARIABLE & $\begin{array}{l}\text { No } \\
\text { Of } \\
\text { Items }\end{array}$ & $\begin{array}{l}\text { Total } \\
\text { Items }\end{array}$ \\
\hline A & VALUE COMPONENTS & (a) & Intrinsic Goal Orientation & 4 & 12 \\
\hline & (b) & Extrinsic Goal Orientation & 3 & \\
\hline & (c) & Task Value Beliefs & 5 & \\
\hline B & & & & \\
\hline & $\begin{array}{l}\text { EXPECTANCY } \\
\text { COMPONENT }\end{array}$ & (a) & $\begin{array}{l}\text { Students Perception of Self- } \\
\text { Efficacy }\end{array}$ & 5 & 7 \\
\hline & (b) & Control Beliefs for Learning & 2 & \\
\hline C & & & & \\
\hline & AFFECTIVE COMPONENTS & & & 24 \\
\hline
\end{tabular}

Table 2- reliability Statistics

\section{Reliability Statistics}

\begin{tabular}{r|r}
$\begin{array}{c}\text { Cronbach's } \\
\text { Alpha }\end{array}$ & N of Items \\
\hline .882 & 24 \\
\hline
\end{tabular}

The questionnaire is distributed to the students which composed of 24 5-point Likert type question for the motivational scale and demographic profile. The participant will be asked to select one of the following alternative: 1: Never; 2: Rarely; 3: Sometimes; 4: very often; and 5: Always. Table 2 shows a Cronbach alpha of .882 for the instrument; thus, showing a high 
reliability for the instrument. The data analysis will be perform using the statistical software of SPSS in which descriptive and inferential statistic will be applied for the quantitative data (Gay, Mills \& Airasian (2009).

\section{Findings}

This section presents the analysed data in terms of percentages and mean scores. The first section presents findings for the demographic while the second section presents data to answer the three research questions.

Findings for Demographic Profile

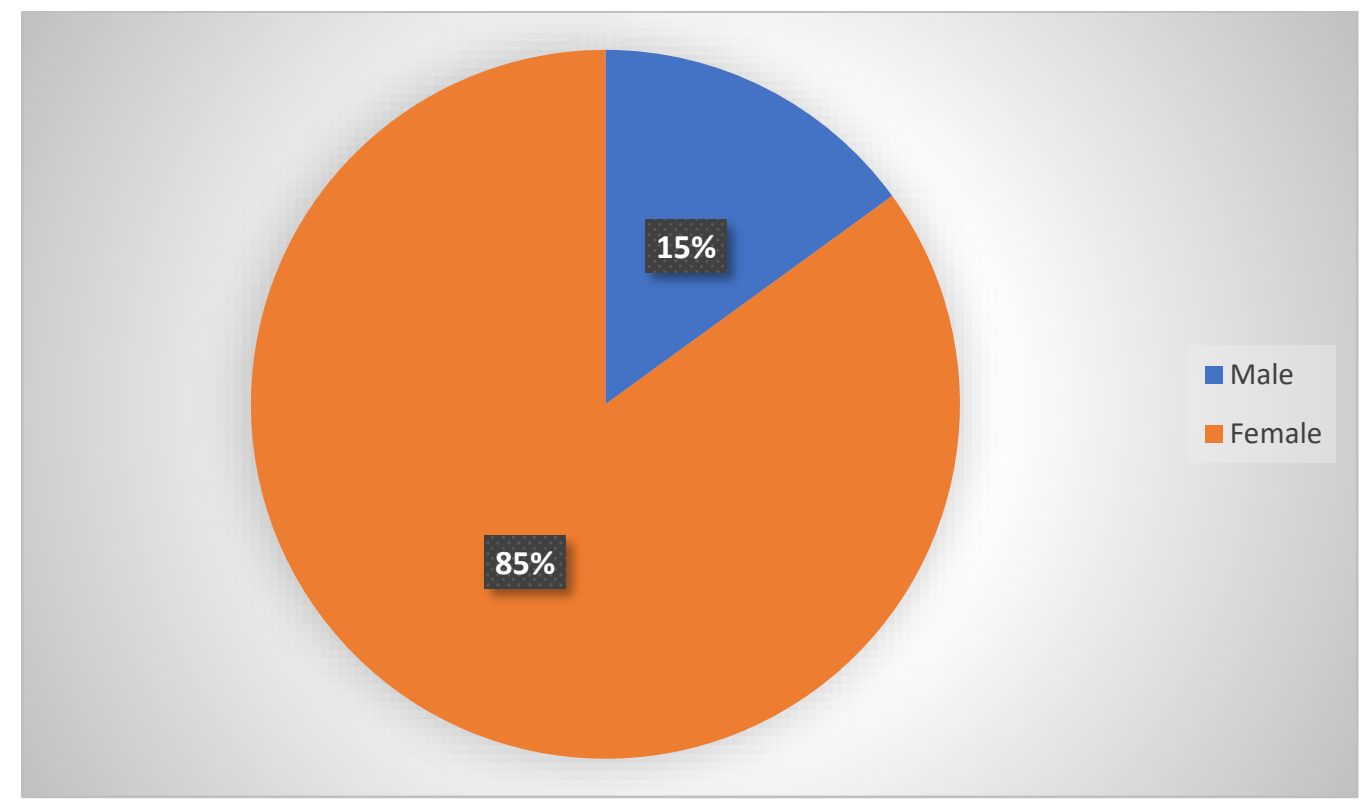

Figure 5-Percentage for Gender

Figure 5 above depicts the percentage of the respondents based on gender. From a total of 89 respondents, $85 \%$ were female ( 76 respondents) while $15 \%$ were male (13 respondents). 


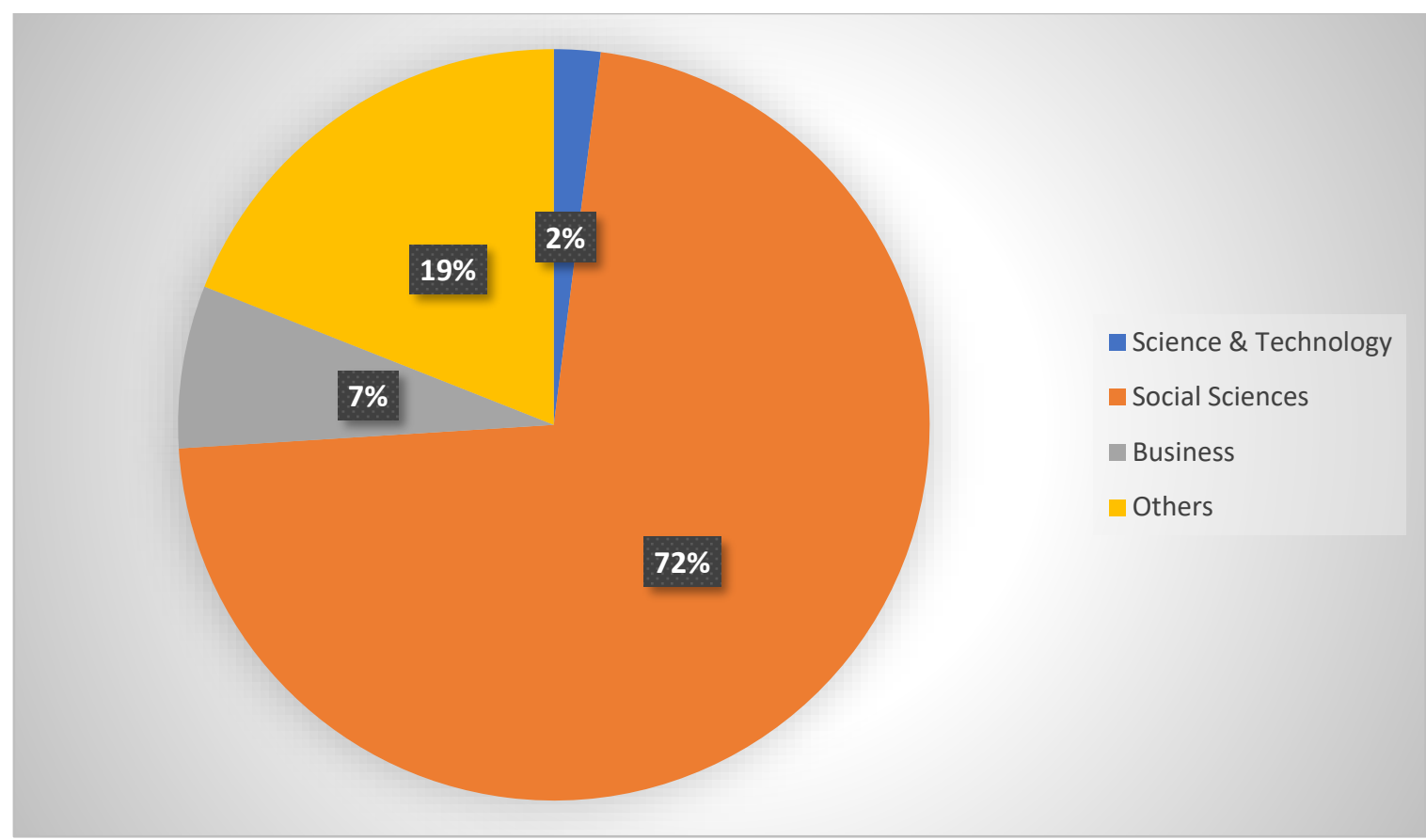

Figure 6-Percentage for Discipline

From Figure 6 the most respondents were from the social sciences disciplines of $72 \%$, followed from others (19\%), business (7\%) and science and technology (2\%).

\section{Findings for Locus Control through Value Components}

This section presents analysed data to answer research question 1: How do value components influence learners' motivation? When it comes to locus of control in learning, learners depended on their value components. Value components are divided into (a) intrinsic goal orientation, (b) extrinsic goal orientation, and (c) task value. 


\section{Intrinsic Goal Orientation}

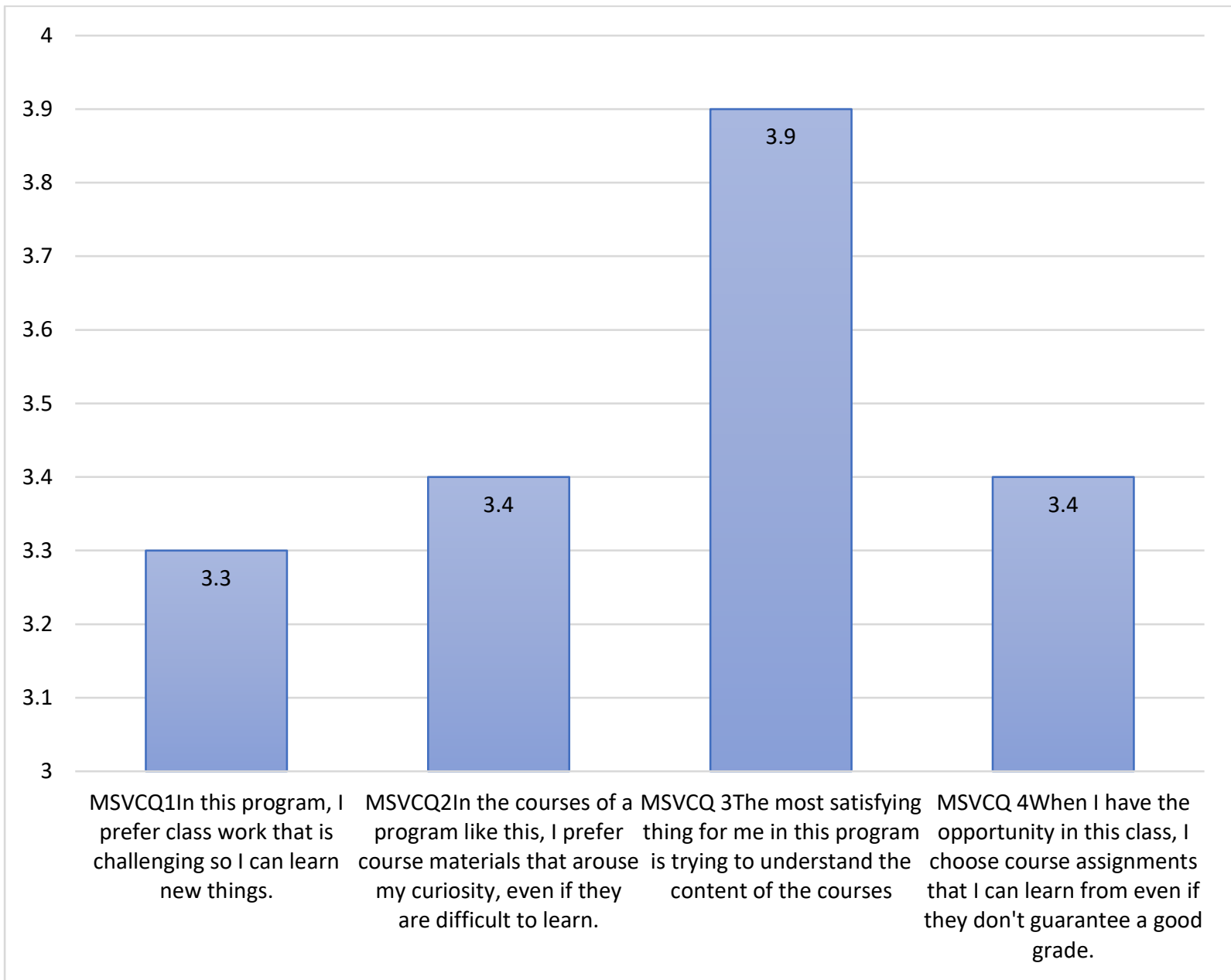

Figure 7-mean for Intrinsic Motivation

Figure 7 above explained the mean findings for intrinsic motivation components which measured by 4 items. All four items were scored moderately high. Item three which is the most satisfying thing for the respondents in this program is trying to understand the content of the course was the highest mean with 3.9. Whereas the second and fourth item were scored evenly. Both mean was scored at 3.4 in which the respondents viewed that in the courses of a program like this, they prefer course materials that arouse their curiosity, even if they are difficult to learn. On the other hand, according to the respondents as when they had the opportunity in this class, they choose course assignments that they can learn from even if they don't guarantee a good grade. The first item (I prefer class work that is challenging so I can learn new things) was scored least mean with 3.3. 


\section{Extrinsic Goal Orientation}

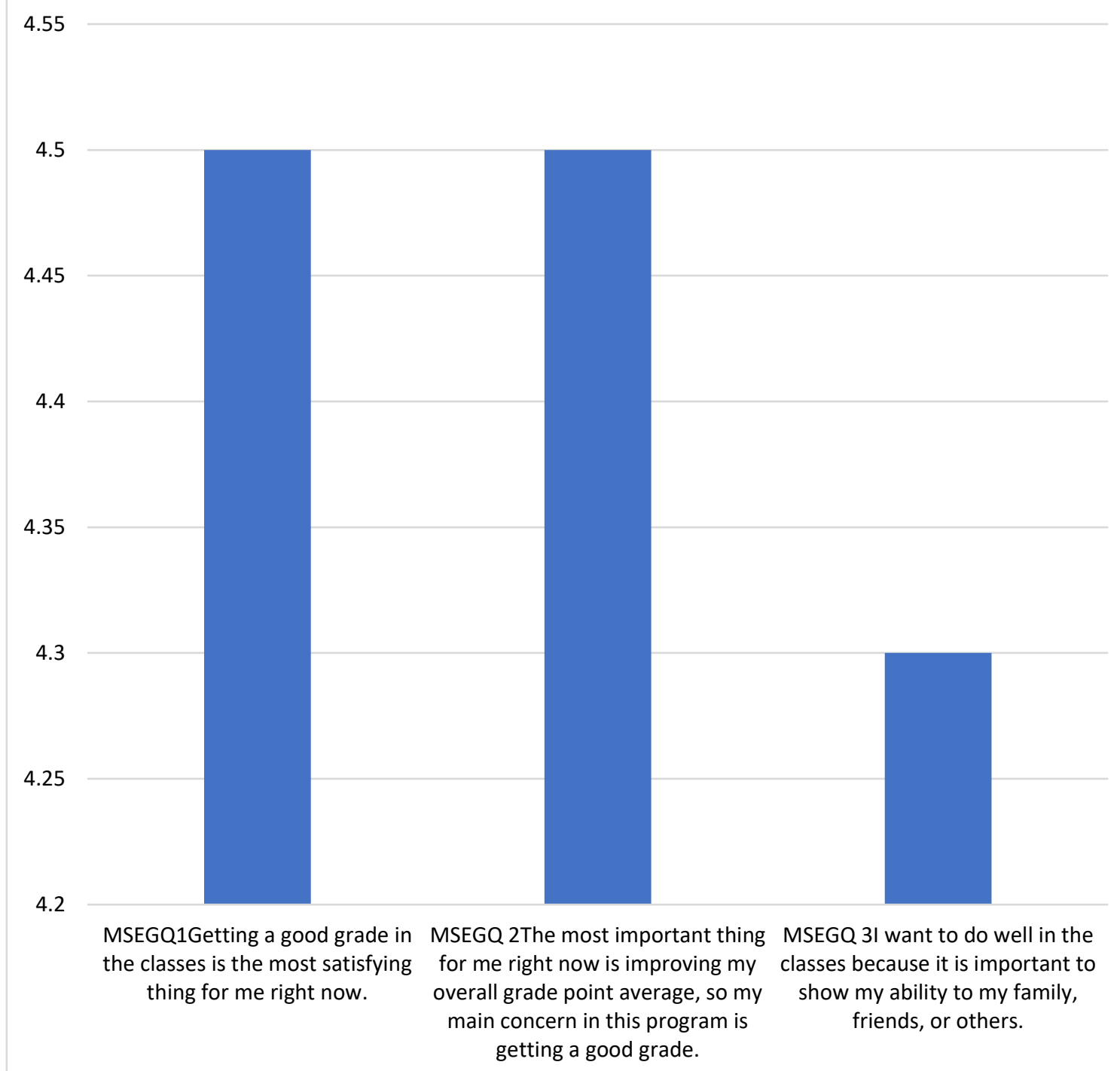

Figure 8-mean for Extrinsic Goal

Figure 8 above depicted the mean findings for extrinsic goal orientation components which measured by 3 items. All three items were scored high. Item 1 which is getting a good grade in the classes is the most satisfying thing for me right now and item 2 namely the most important thing for me right now is improving my overall grade point average, so my main concern in this program is getting a good grade scored high mean value of 4.5 respectively while item 3 which is I want to do well in the classes because it is important to show my ability to my family, friends, or others also scored high mean value (4.3). This high mean scores pointed out that the respondents agreed that good grades and do well in class fulfil their extrinsic goal orientation thus motivates them well in the learning process. 
Task Value Beliefs

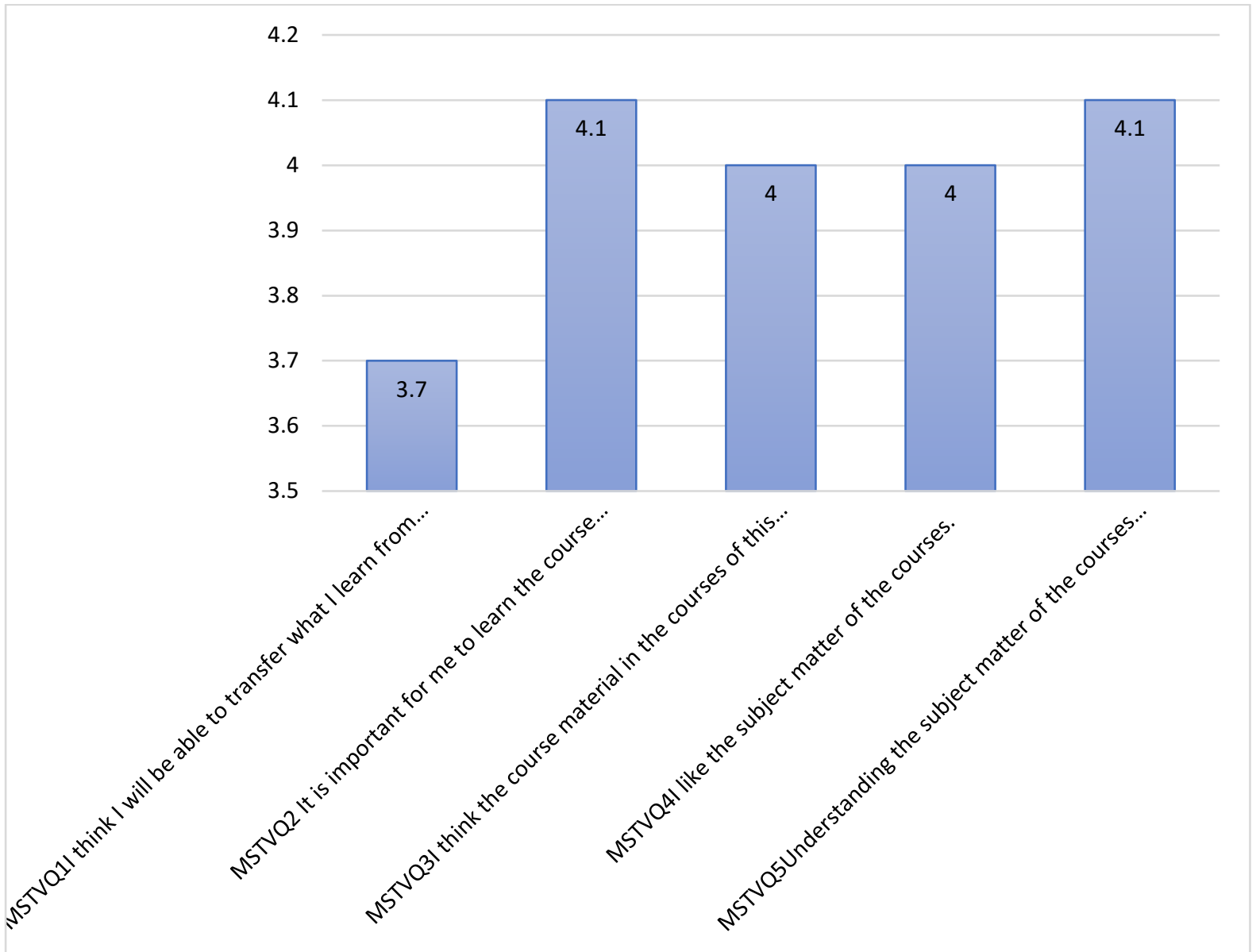

Figure 9 shows the -mean for Task Value.

Based from the findings, there are two components that most concern the respondents (figure 9). The first one is it is important for the respondents to learn the course materials in the course and the second one is understanding the subject matters of the courses is very important to the respondents. Both are with the highest mean of 4.1 and this proved that understanding is the most value elements in beliefs. Other than that, the respondents also agreed that the course material in the courses of this program is useful for them learn (mean 4.0) and they like the subject matter (mean 4.0). The lowest mean is 3.7 is about the beliefs among respondents that they able to transfer what they learn from this course to other courses in the program.

Findings for Controllability through Expectancy Components

This section presents findings to answer research question 2: How do the expectancy components influence learners' motivation? Learners gain controllability through factors in the expectancy components. In the context of this study, expectancy components are measured through (a) students' perception of self-efficacy, and (b) control beliefs for learning. 


\section{Students 'Perception of Self-Efficacy}

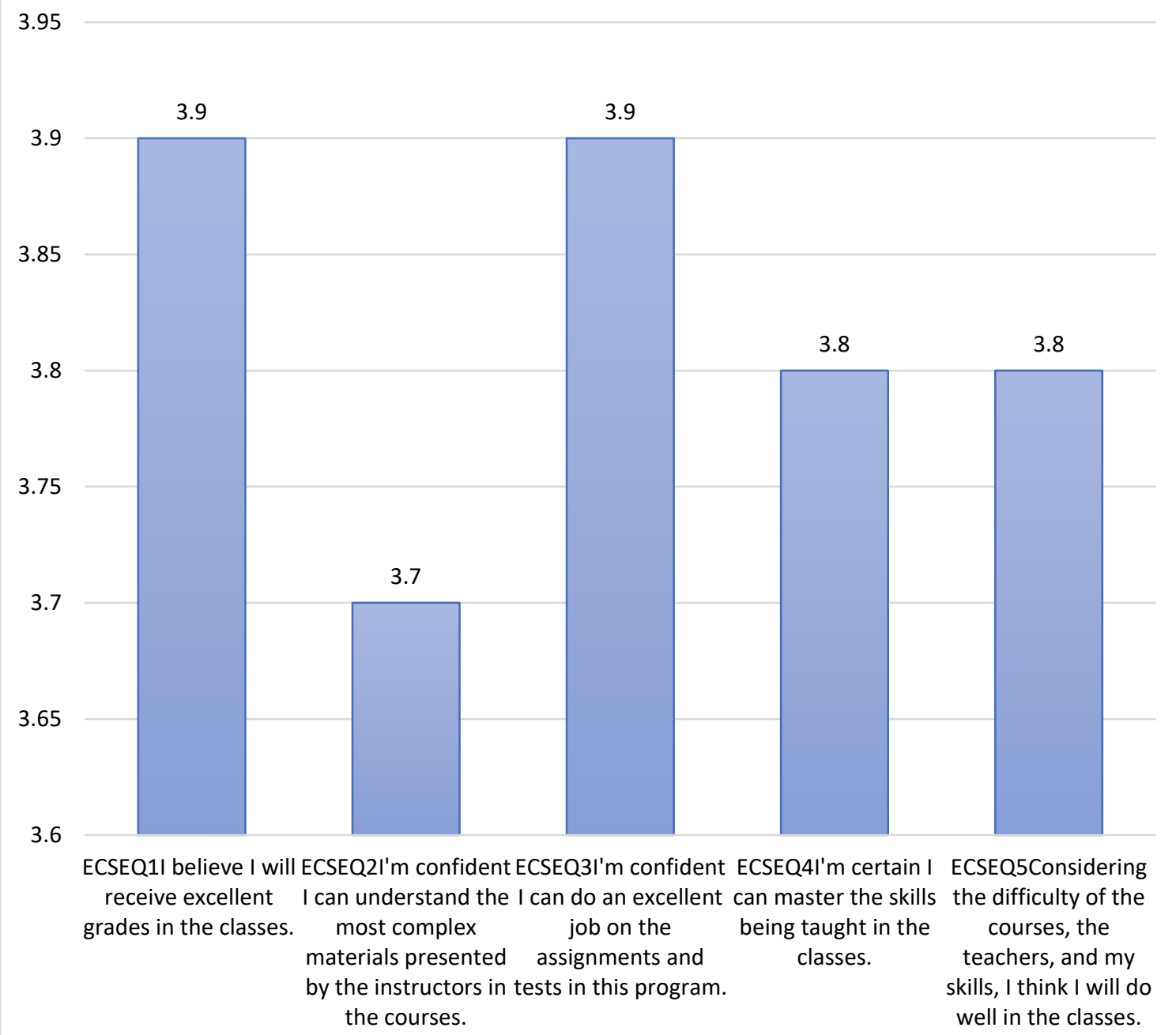

Figure 10 -mean for Self-Efficacy

Figure 10 depicted the findings on student's perception of self-efficacy with 5 items was measured. In first item, the respondents believe they will receive excellent grades in the classes and in third item they also confident that they can do an excellent job on assignments and tests in this program. Both mean for this item was 3.9 Meanwhile for another item (Item 4 and item 5) were scored the mean with 3.8. In item 4 they are certain that they can master the skills being taught in the classes and item 5 , they think they will do well in the classes despite the difficulty of the courses, the teachers and their skills. The item 2 which measure on the respondent confident level of understanding the most complex materials presented by the instructors in the course are scored least mean with 3.7. 


\section{Control Beliefs for Learning}

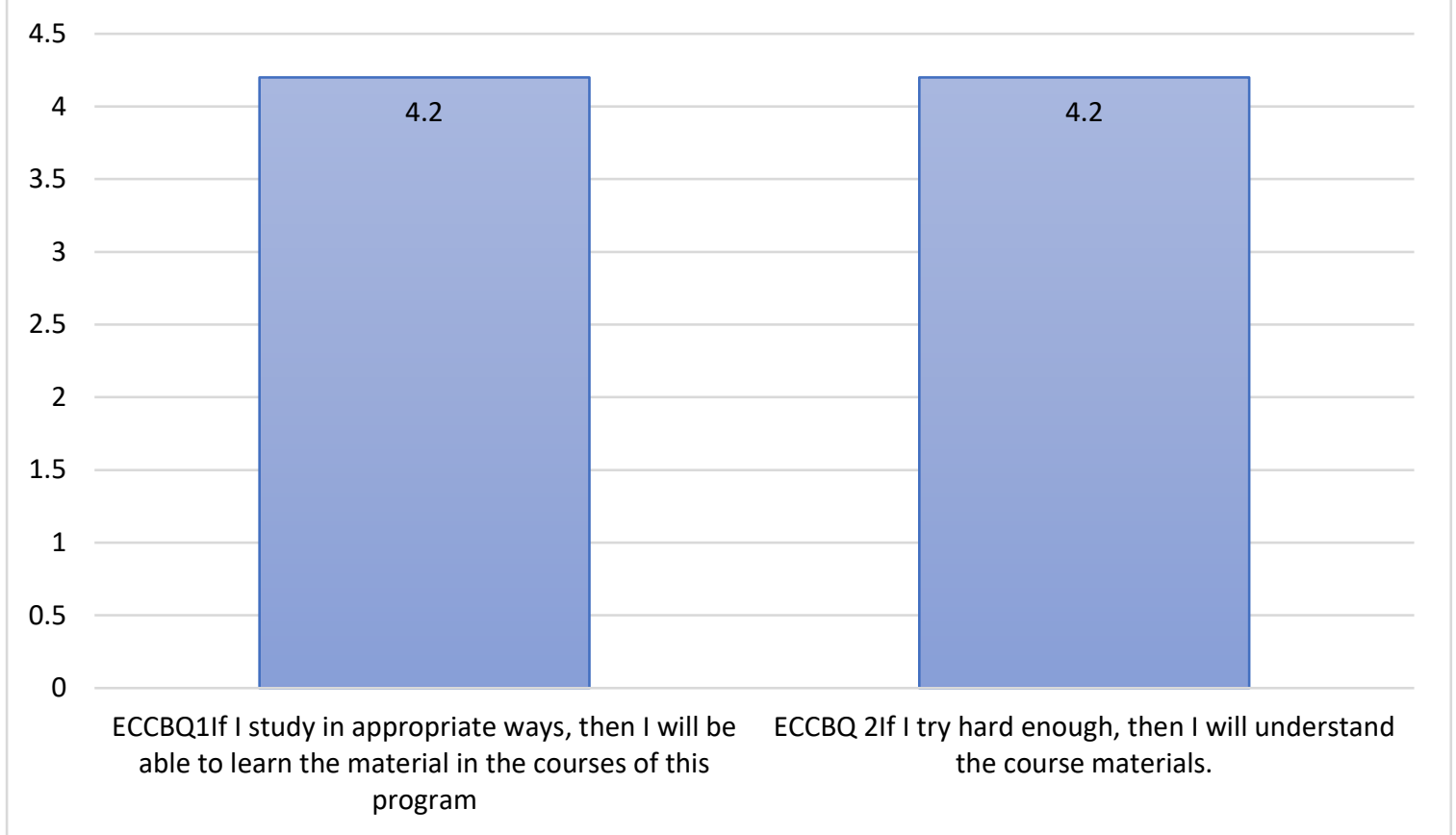

Figure 11-mean for Control Beliefs

Figure 11 shows the control beliefs for learning which shared the same mean value, 4.2. These mean values can be considered as high which means that the students believe if they study in appropriate ways and hard enough, hence they will be able to understand and learn the material in the courses program.

\section{Findings for Stability through Affective Components}

This section presents findings to answer research question 3: How do the affective components influence learners' motivation? Learners stability depends on affective components.

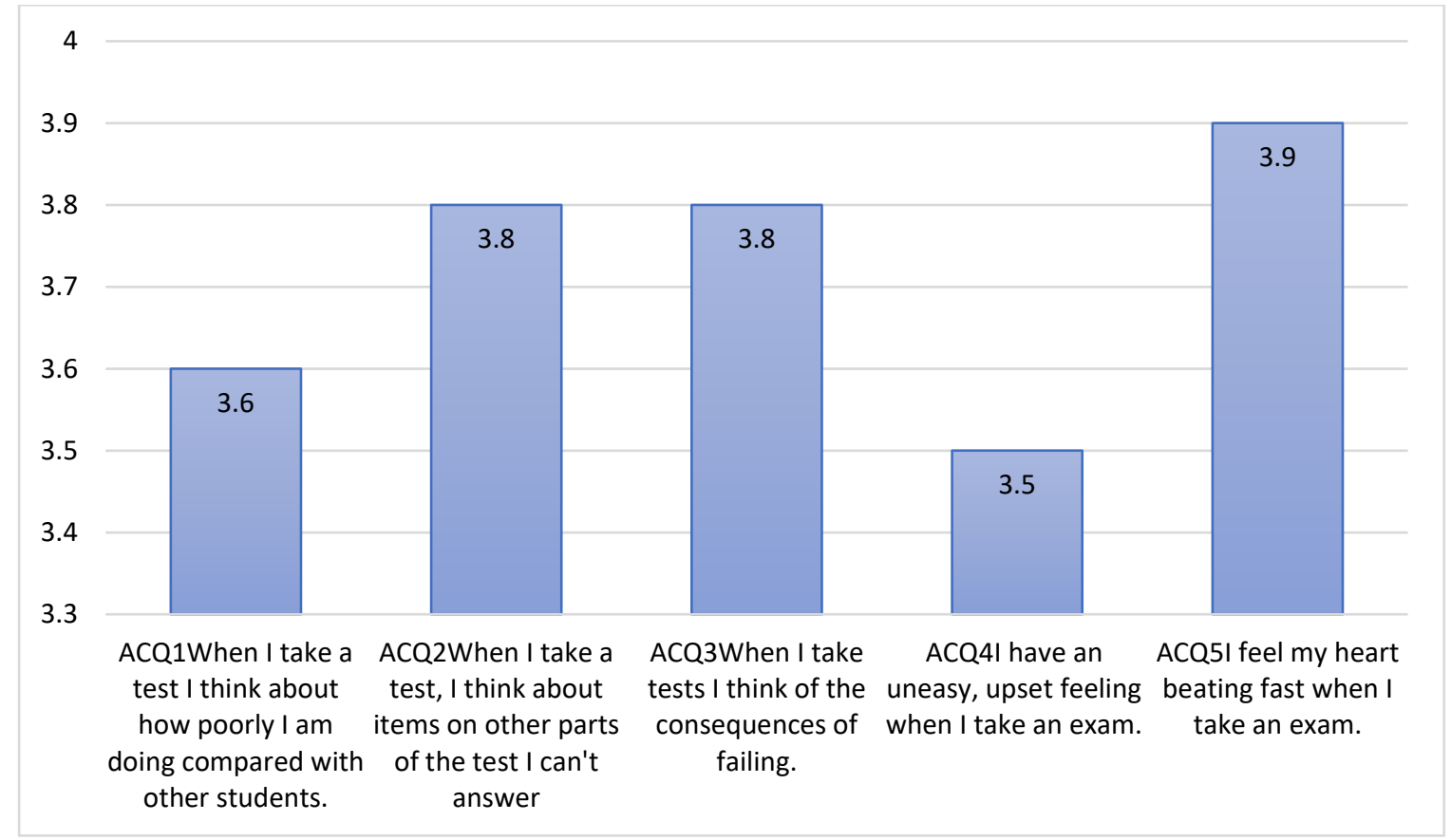

Figure 12-Mean for Affective Component 
Figure 12 highlighted about the findings on an affective components with 5 items measured. Overall, the mean score was moderate. The highest mean was item 5 which respondents feel their heart beating fast when they took an exam. As for item 2 when the respondents take a test, they think about items on other parts of the test that they can't answer. Meanwhile on item 3, is about when the respondents take tests they think of the consequences of failing and for this both item mean scored are at 3. 8. The lowest mean score was at 3.6 which measured on the respondents taught when they took a test that they think about how poorly they are doing compared with other students -mean for Affective

\section{Conclusion}

\section{Summary of Findings and Discussion}

This study has shown an interesting finding about learners' motivation on different types of presence in learning Social Marketing as a subject with heavy group project elements online. When it comes to first research objective on value components, three components were measured which is, intrinsic goal orientation, extrinsic goal orientation and task value belief. As for the intrinsic goal orientation social, the most satisfying thing for therespondents in this program is trying to understand the content of the course (3.9), meanwhile the item about the respondents prefer class work that is challenging so they can learn new things were the least mean score (3.3). On the next value component which is measuring extrinsic goal orientation, the findings from the study revealed some interesting facts. All items in this components score a high mean in a range of 4.5-4.3. And the last components were on task value belief which also record a high mean score in the range of 4.0-4.1. Both of the item scored at 4.1 which is on the important for me to learn the course materials in the courses and also on understandings the subject matter of the courses is very important to me. This is also reported by Esra and Sevilen (2021) that higher levels of engagement in the activities, classes and tasks were relevant and meaningful to the learners. The enjoyment in the course content and self discipline were contributed to increased students' motivation.

Next, when it comes to expectancy components, it measures student's perception on selfefficacy as well their control belief in learning. As for student's perception on self-efficacy they are confident that they can do an excellent job on the assignments and tests in this program. They even believe that they will receive excellent grades in the classes for this subjects. This two were scored at 3.9. Meanwhile for the second components in expectancy components on the control beliefs for learning can be considered as high which means that the students believe if they study in appropriate ways and hard enough, hence they will be able to understand and learn the material in the courses program. The study by Juhana (2012) concur to this finding of this study that It is crucial to motivate students to learn because better academic results can be achieved if the student had substantial motivation to succeed compared to those who has not.

Next, this study measure on affective components. This study showed that the learners feel their heart beating fast when they took an exam and when the respondent take a test, they think about items on other parts of the test that they can't answer.

\section{Pedagogical Implications and Suggestions for Future Research}

Motivation is one of the most significant factors that influence learners to learning. It is very crucial for both teachers and learners to develop trust between them. This will ease the learning process. This is become more critical when the subjects are teach using online 
learning mode. With the Social marketing subject are heavy in group projects, thus is more important in making sure the level of motivation from both sides are at the optimum level. The approach in pedagogical is crucial in order to motivate the learners, especially in the subjects that heavily depends on group works like Social Marketing.

Future researchers could look into how different courses that conducted using online mode will influence the learner's motivation in learning. Interviews can be done to seek an indepth view of learners (and teachers) on how to motivate themselves in learning such courses.

\section{References}

Aladdin, A. (2013). Demotivating Factors in the Arabic Language Classroom: What demotivates non-Muslim Malaysian learners when it comes to learning Arabic?. Procedia-Social and Behavioral Sciences, 93, 1652-1657. Retrieved from https://reader.elsevier.com/reader/sd/pii/S1877042813035416?token=DCBE6AE787D 88D341ED347410C8F66A177FB7E7E6F199F5E5A8CC8F9C650801E58425D951C0B734 23A0FB3BA80B05509\&originRegion=eu-west-1\&originCreation=20211024095443.

Alonso-Tapia, J., Ruiz, M. Á., \& Huertas, J. A. (2020). Differences in classroom motivational climate: causes, effects and implications for teacher education. A multilevel study. Anales De Psicología/Annals of Psychology, 36(1), 122-133. Available at https://doi.org/10.6018/analesps.337911

Daggol, G. (2013). The reasons of lack of motivation from the students and teachers voices. The Journal of Academic Social Science, 1(1), 35-45. DOI: 10.16992/ASOS.13

Deci, E. L., and Ryan, R. M. (1985). Intrinsic Motivation and Self-determination in Human Behaviour. New York: Plenum

Dörnyei, Z., \& Ushioda, E. (2013). Teaching and researching motivation, second edition. Teaching and Researching Motivation, Second Edition. Retrieved from https://doi.org/10.4324/9781315833750

D'Orazzi, G. (2020). University Students' Demotivation in Learning Second Languages. International Journal of Literacy, Culture, and Language Education, 1, 28-53. Available at DOI 10.14434/ijlcle.v1i0.31151

Elena, S. (2021). Students Motivation's and Engagement during Distance Learning. International Journal of Science and Research, 10 (1), 1462-1466. Available at DOI: $10.21275 /$ SR21126103143

Esra, M. E. Ş. E., \& Sevilen, Ç. (2021). Factors influencing EFL students' motivation in online learning: A qualitative case study. Journal of Educational Technology and Online Learning, 4(1), 11-22. Available at http://doi.org/10.31681/jetol.817680

Falout, J., Elwood, J., \& Hood, M. (2009). Demotivation: Affective states and learning outcomes. System, 37(3), 403-417. Available at

https://doi.org/10.1016/j.system.2009.03.004

Filgona, J., Sakiyo, J., Gwany, D. M., \& Okoronka, A. U. (2020). Motivation in learning. Asian Journal of Education and Social Studies, 16-37. Available at DOI: $10.9734 /$ ajess/2020/v10i430273

Gorham, J., \& Christophel, D. M. (1992). Students' Perceptions of Teacher Behaviors As Motivating and Demotivating Factors in College Classes. Communication Quarterly, 40(3), 239-252. https://doi.org/10.1080/01463379209369839 
Juhana, J. (2012). Psychological factors that hinder students from speaking in English class (A case study in a senior high school in South Tangerang, Banten, Indonesia). Journal of Education and Practice, 3(12), 100-110. Retrieved from https://www.iiste.org/Journals/index.php/JEP/article/view/2887/2913

Leal-Sotoi, F., Carmona-Halty, M., Dávila-Ramírez, J., \& Valdivia, Y. (2018). Work Engagament, Teaching Practices With Motivational Climate. Revista Interamericana de Psicología, 52(2), 162-170. Available at https://doi.org/10.30849/rip/ijp.v52i2.106

López, M. G., \& Tun, B. M. (2017). Motivating and demotivating factors for students with low emotional intelligence to participate in speaking activities. Profile Issues in Teachers Professional Development, 19(2), 151-163. Available at http://dx.doi.org/10.15446/profile.v19n2.60652.

Motevalli, S., Perveen, A., \& Michael, M. T. A. (2020). Motivating Students to Learn: An Overview of Literature in Educational Psychology. International Journal of Academic Research in Progressive Education \& Development, 9(3), 63-74. Available at http://dx.doi.org/10.6007/IJARPED/v9-i3/7779

Palmer, D. (2007). What is the best way to motivate students in science?. Teaching Science, 53(1), 38-42. Available at DOI: 10.12691/education-3-8-18

Pintrich, P. R., \& De Groot E. V. (1990). Motivational and self-regulated learning Components of classroom academic performance. Journal of Educational Psychology, 82(1), 33-40. Available at http://dx.doi.org/10.1037/0022-0663.82.1.33

Rahmat, N. H., Sukimin, I. S., Mok, S. S., Anuar, M., and Mohansas, E. S. (2021) Online learning Motivation and Satisfaction: A Case Study of Undergraduates \& Postgraduates. International Journal of Asian Social Science, Vol 11(2), pp 88097. Retrieved from https://doi.dx./ 10.18488/journal.1.2021.112.88.97

Rana, A., Gulati, R., \& Wadhwa, V. (2019). Stress among students: An emerging issue. Integrated Journal of Social Sciences, 6(2), 44-48. Retrieved from http://www.pubs.iscience.in/journal/index.php/ijss/article/viewFile/891/578.

Rufii, R., \& Rochmawati, D. (2019). Evaluation of universal design for constructivist-based statistics learning module for students' increased motivation. Journal of Education and Learning (EduLearn), 13(3), 431-440. Available at DOI: 10.11591/edulearn.v13i3.9174

Ryan, R. M., Deci, E. L. (2002). Overview of self-determination theory: an organismic dialectical perspective. In: Deci, E.L., Ryan, R.M. (Eds.), Handbook of Self-determination Research. University of Rochester Press, Rochester, NY, pp. 3-33.

Ushida, E. (2005). The role of students' attitudes and motivation in second language learning in online language courses. CALICO journal, 23 (1), 49-78. Retrieved from file://C:/Users/Acer/Downloads/23165-64163-1-PB.pdf.

Vallerand, R. J., Ratelle, C. F. (2002). Intrinsic and extrinsic motivation: a hierarchical model. In: Deci, E.L., Ryan, R.M. (Eds.), Handbook of Self-Determination Research. University of Rochester Press, Rochester, NY, pp. 37-63.

Vroom, V. H., \& Deci, E. L. (1970). Management and Motivation. UK: Penguin.

Vibulphol, J. (2016). Students' Motivation and Learning and Teachers' Motivational Strategies in English Classrooms in Thailand. English Language Teaching, 9(4), 64-75. Available at DOI:10.5539/elt.v9n4p64

Williams, K. C., \& Williams, C. C. (2011). Five key ingredients for improving student motivation. Research in Higher Education Journal, 12, 1-23. Retrieved from http://aabri.com/manuscripts/11834.pdf 
Weiner, B. (1974). Achievement motivation and attribution theory. Morristown, N.J.: General Learning Press.

Yensy, N. A. (2018). Increasing the Students' Learning Motivation and Understanding of Concept by Using Examples and Non-Examples Learning. ICETeP. Advances in Social Science, Education and Humaities Research, 295, 17-20. Retrieved from https://www.atlantis-press.com/proceedings/icetep-18 